\title{
FACTORS SUPPORTING THE SUCCESS OF COMMUNITY-BASED TOURISM IN CILETUH GEOPARK
}

\author{
Nurlena $^{1}$, Musadad ${ }^{2}$ \\ ${ }^{1}$ Telkom University. Indonesia \\ ${ }^{2}$ Riau University. Indonesia \\ musadad@1ecturer.unri.ac.id
}

\begin{abstract}
Compared to 15 villages located in Ciletuh Geopark, Tamanjaya is the center of geotourism activities and the village has the most rapid progress, as well as has active tourism management. Therefore, this study was aimed to identify the factors supporting the success of the Community-Based Tourism (CBT) project in Tamanjaya Village and explore the community's constraints in participating in the project. This study employed a qualitative method from which the data was collected through field observations and semi-structured interviews with various stakeholders and local residents. The thematic analysis results suggested that the success factor of the CBT project in Tamanjaya Village cannot be separated from some involved parties, ranging from the private sector, academia, and governmental institutions. Meanwhile, the local residents' barriers to participation in the tourism activities include the community's lack of interest in the tourism activities, busy activities in household affairs, and lack of tourism knowledge of Ciletuh Geopark.
\end{abstract}

Keywords: Community-Based Tourism; Success Factors; Geopark

\section{INTRODUCTION}

One of the potential efforts that can be done to preserve culture and nature in the frame of tourism is to create a geopark. The geopark concept serves as a tourist destination that can accommodate the phenomenon of tourism which is oriented to diversity or natural and cultural beauty.

Geopark as an alternative to tourism development will further strengthen the image of sustainable tourism in Indonesia. Currently, Indonesia continues to try to build a Geopark and has succeeded in making one of its geoparks recognized by UNESCO as a part of Global Geopark Network (GGN), i.e. Ciletuh Geopark. The success of Ciletuh Geopark as a part of GGN cannot be separated from the collaboration of various parties, including research.

In early 2018, Ciletuh Geopark was recognized as a part of the Global Geopark Network (GGN). But before that, many efforts have been made so that the geopark is designated by UNESCO as a world heritage park. The efforts started with the preliminary study in 2015, the acceleration of development in 2017, and 
others. The Ciletuh Geopark destination is located in Palabuhanratu, Sukabumi Regency, West Java.

The name of Ciletuh Geopark is determined through the Sukabumi Regent Decree No. 556/Kep.684-Disparbudpora/2014, and includes 15 Villages, and its territory encompasses various administrative areas such as Nature Reserves, Military Areas, Conservation Areas, and others (Hardiyono et al, 2015). So, there it has been a long time since the initiation of the formation of the Ciletuh Geopark.

One of the actors in developing a geopark is the local community. Therefore, the community is a factor cannot be ignored in a geopark management so that a geopark also requires the concept of community-based tourism.

Community-based tourism (CBT) is an approach in tourism that tries to accommodate community participation in the management. Goodwin \& Santilli (2009) defines CBT simply as tourism that is owned and/or managed by the community and is intended to provide benefits to the community.

According to Scheyvens (2002), the ultimate goal of CBT is the empowerment of the host community. CBT is believed to be able to provide collective benefits, creating opportunities for micro-scale employment, and business engagement (Mann, 2000). However, CBT also comes with various risks. Some studies, for example, find that the income generated from CBT is relatively small and it has poor governance (Mitchell \& Muckosy, 2008). Other researchers, in term of the CBT shortage, also found a lack of local community participation (Scheyvens, 2002), potential conflicts between citizens due to unfair distribution of benefits (Häusler \& Strasdas, 2002), mismanagement of funding, and the exclusion of other stakeholders (Strydom \& Mangope, 2017). Therefore, Giampiccoli et al (2015) emphasize the importance of capacity building and empowerment supported by advocacy to make the community independent in anticipating the risks of failure of a community-based tourism project. Implicitly, Kontogeorgopoulos et al (2014) concluded that the keys to the success of a CBT project include the role of luck, external support, and local leadership.

CBT projects are not always successful. Blackstock (2005) suggested a failed CBT project in Port Douglas, a tourism destination in Australia, due to three factors, including taking a functional approach to community involvement, treating the host community as a homogeneous bloc, and disregarding the structural constraints to local control of the tourism industry. In addition, Stone \& Stone (2011) reported that a CBT project in Khama Rhino Sanctuary Trust, Botswana was unsuccessful because of the community dissatisfaction about loss of cattle grazing and other land-related advantages, lack of communication with the locals, less numbers of employed people, lack of benefits, and the slow improvement of the project. 


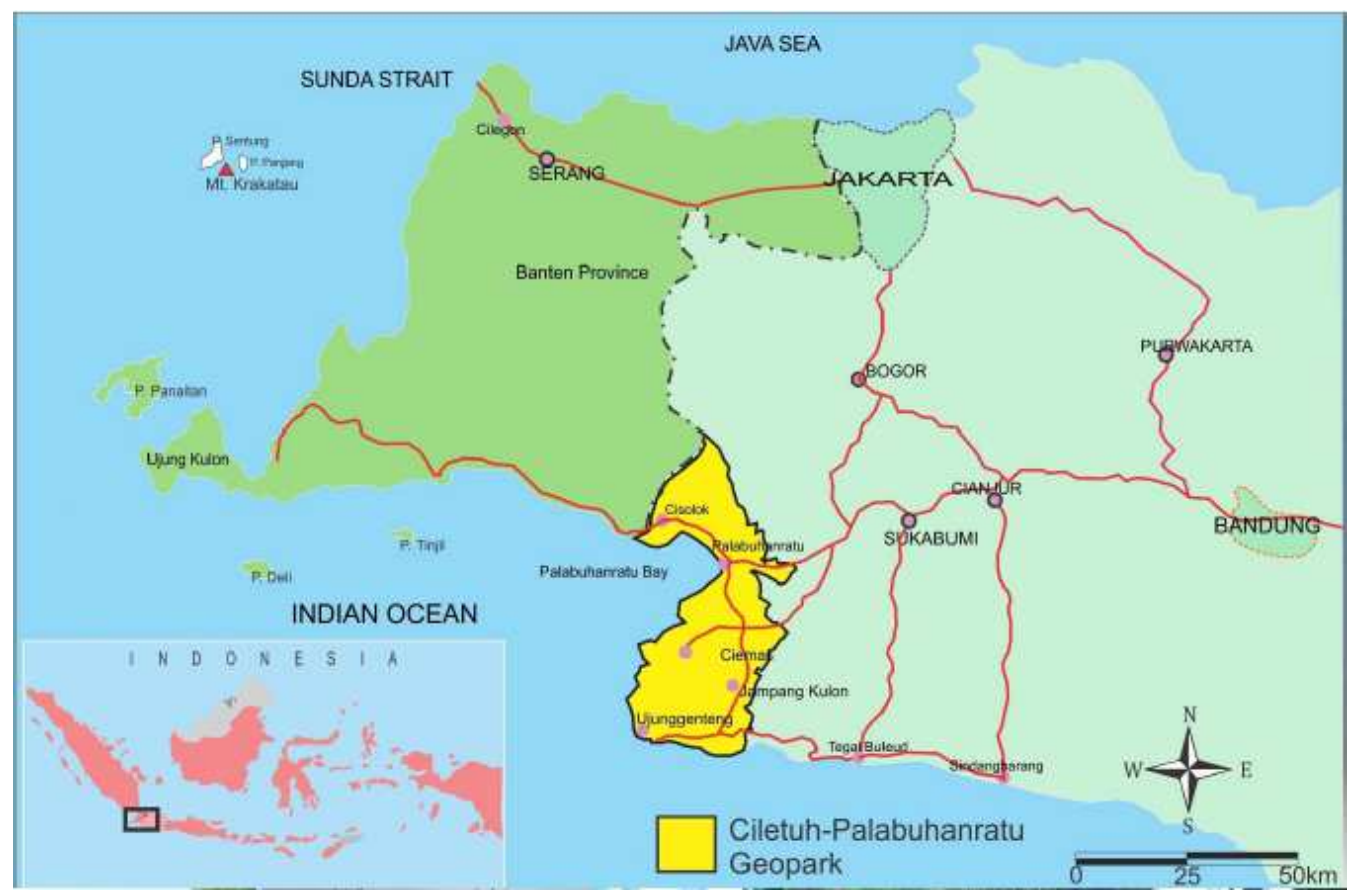

Figure 1. Ciletuh Geopark Area

Source: UNPAD's Geopark and Geological Disaster Research Center, 2017

In Ciletuh Geopark, the village that is considered successful in implementing the concept of community-based tourism is Tamanjaya village. In the village, PT Bio Farma said in 2015, there were 21 small businesses where the number of homestays grew from only 2 units in 2013 to 23 units in 2015 and tourism has created jobs for 18 tour guides. In addition, according to Darsiharjo et al (2016), Tamanjaya Village is the center of geotourism activities in Ciletuh Geopark area and has the most rapid progress compared to other villages They also found that the local residents are very active in the management of Ciletuh Geopark area.

The above description of CBT in Tamanjaya village has indicated the success of the project in the village as there are two success criteria for a CBT project, i.e. community ownership/management and community benefits (Goodwin \& Santilli, 2009). Meanwhile, according to Asker et al (2010), in order for CBT to be sustainable, the community must participate and benefit from tourism development. Thus, based on the description above, this study was aimed at:

1) Identifying the factors supporting the successful implementation of Community-Based Tourism in Ciletuh Geopark by taking the case of Tamanjaya Village.

2) Identifying the community's constraints on participating in tourism activities.

This study is very useful for the enrichment of tourism theories, especially those relating to Community-Based Tourism (CBT). As it is known, a CBT cannot be separated from the management and benefits received by the community, such as social and cultural benefits. Thus, identifying the success factors and the constraints to community participation would become an important reference to efforts in making a community-based tourism project sustainable. Therefore, the 
implications of this research can be seen from the aspects of policy (practical) and scientific (theoretical).

\section{METHODOLOGY}

This study applied a qualitative method so the sources of the data in this study were in the form of qualitative data. The primary data was collected from interviews with several parties understanding tourism dynamics at Tamanjaya Village, direct observations in the field, and documentation. Meanwhile, the secondary data in this study included supporting documents such as news data on the internet, location maps, and others.

a) Interviews with stakeholders who understand about Tourism Activities in Ciletuh Geopark, especially those located in Tamanjaya Village, such as PAPSI (Paguyuban Alam Pakidulan Sukabumi), Sukabumi Tourism Office, and local communities. The interviews were conducted to elicit the data on tourist attractions, history of tourism in the village, forms of community's participation in the tourism activities, and the constrains to their participation.

b) Direct observation to find out and identify directly the existing condition and situation of tourism in Tamanjaya Village. Observations were focused on aspects of facilities, tourist attractions, and management.

c) Documentation was to view or analyze documents created by the subject itself or by others about the subject, including legal or non-legal documents related to the research topic. The documents include university's research report on Ciletuh Geopark, government report, and journal articles discussing the history, potential, and the development of the geopark.

The data collected from interviews and observations were analyzed using an interactive analysis model developed by Miles and Huberman (2014). There are three components performed in this model, including reduction, display, and verification/conclusion drawing.

\section{RESULTS AND DISCUSSION}

Tamanjaya Village is one of the villages located in Ciemas Sub-District. It is also part of the Ciletuh Palabuhanratu National Geopark. This village consists of 4 villages, namely Tamanjaya Hamlet, Cicurug Hamlet, Pasirbaru Hamlet, and Ciseureuh Hamlet.

The majority of the residents work as farmers with rice as the main commodity. Tamanjaya Village is a village that originated from the division of Mekarjaya Village, which was once belonged to Cirameng hamlet, a part of Mekarjaya Village, Ciemas Sub-District.

The name Cirameng comes from the name of one of the tributaries that divide Tamanjaya Village and empties into the Ciletuh River. The main reason for the expansion of the area is the factor of the increasing population in Mekarjaya Village. In addition, the community commonly earns a living as farmers with a very strong culture and strategic location. 


\section{Tourism Attractions in Tamanjaya Village}

Tamanjaya village as one of the villages located in the Ciletuh Geopark Area has tourism potential as part of the geopark area. The tourism potential is an inseparable part of management by the surrounding community (community-based tourism). From the results of the UGM KKN report (https://tamanjaya.desa.id/), there are several tourist attractions, namely: Awang Waterfall, Puncak Manik Waterfall, Panyawangan Cekdam, Panenjoan, Central Curug, and Cigaok Cultural Village.
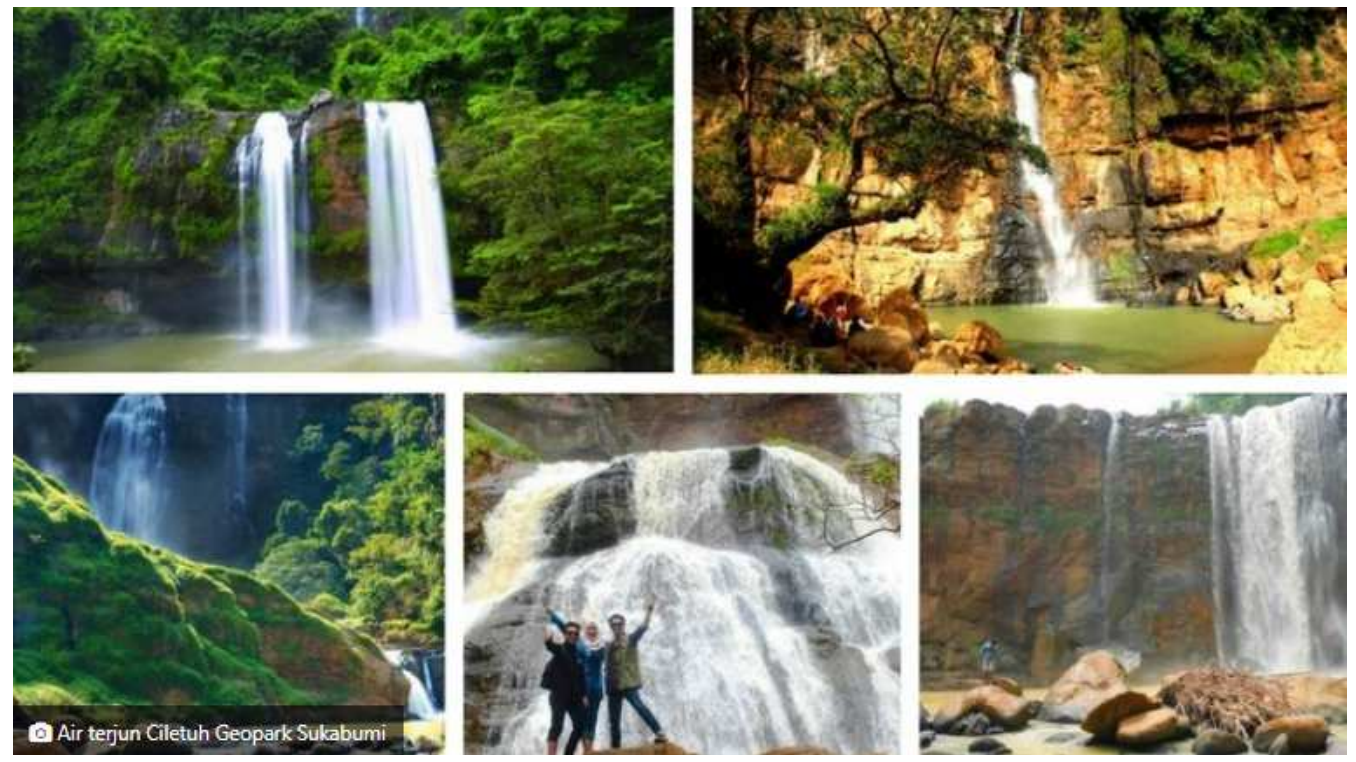

Figure 2. natural Attractions in Ciletuh Geopark Source: sabumiku.com

1) Curug Awang

Awang Waterfall is one of the waterfalls of the Ciletuh river located in Taman Jaya village, Ciemas sub-district, Sukabumi regency. Awang Waterfall has a height of around 40 meters with a width of around 60 meters. About 300 meters downstream, there is a Tengah Waterfall with a height of about 5 meters. About 500 meters downstream and Tengah Waterfall, there is Puncak Manik waterfall with a height of approximately 100 meters. These three waterfalls consist of bedrock in the form of sedimentary rock layers of tuff sandstone and breccia parts of the Jampang Formation of the Lower Miocene Cikarang Member (23-16 million years old). These three waterfalls are formed because of the tectonic process which also forms the Ciletuh mega amphitheater.

Based on legend, Awang Waterfall has an interesting past story behind its beauty. 'Awang' means seeing or observing. It is said that in ancient times, there was a woman who was usually called Eyang Suranimang. Because the Awang waterfall has the highest position between the two other waterfalls, namely Tengah Waterfall and Puncak Manik Waterfall, then Eyang Suranimang liked to be in the Awang waterfall to see the stars as a determinant of planting time. In addition, Awang Waterfall was also used by Eyang Suranimang as a place to find "revelation" when 
receiving complaints from the community.

2) Curug Puncak Manik

This waterfall is about 600 meters from Tengah Waterfall and is still on the Ciletuh River which is the boundary between Tamanjaya Village and Cibenda Village. This waterfall can be reached by foot through rice fields and ridge hills for one hour from the car park.

3) Panyawangan Cekdam

Panyawangan Cekdam is one of the artificial tourist attractions. This attraction is made by the local community to explore the natural scenery around the village. This scenery is considered quite exotic because of the height of the place.

4) Panenjoan

Panenjoan is in the form of Geopark Ciletuh viewing post which is shaped like an amphitheater or horseshoe from a hill with a height of 400 meters above sea level. The word "Panenjoan" itself means "place to see" in the Sundanese language. As seen, this post is a suitable location to enjoy the natural scenery of Ciletuh Geopark.

Bukit Panenjoan is currently a popular tourist spot in Ciletuh Geopark because of its fairly easy access and complete supporting facilities such as food stalls, a prayer room and a parking lot. The location itself is directly opposite the PAPSI office where visitors can get a wealth of information about Ciletuh Geopark.

To enter this area is free because it has not been officially managed by the government. The visitors only need to pay for the parking space if they bring a vehicle, i.e. Rp. 3,000 for motorbikes and Rp. 5,000 for cars.

5) Curug Tengah

This waterfall is about 200 meters from Awang Waterfall and is still on the Ciletuh River which is the border between Tamanjaya Village and Cibenda Village. This waterfall can be reached by foot through the rice fields for 15 minutes from the car park.

6) Cigaok Cultural Hamlet

As a hamlet that will be used as the basis of a cultural center, Cigaok hamlet has quite a lot of tourism potential. One of the Ciletuh geopark icons, Panenjoan, is also located in the Cigaok hamlet area. In addition, the original attractions of Cigaok hamlet include the existence of producers of traditional brown sugar and banana chips that can be used as an icon of tourism from the Tamanjaya Village area. This tourism potential can be developed by showing visitors how to make brown sugar and banana chips that are still traditional. Besides showing the way of making, the products of brown sugar and banana chips can be sold directly to visitors as a special souvenir from Tamanjaya Village.

\section{Factors Supporting the Success of CBT in Tamanjaya Village}

According to Goodwin \& Santilli (2009), there are two criteria for the success of a CBT project, i.e. community ownership/management and community benefits. Both have been felt by residents of Tamanjaya Village. So, the two criteria for a CBT success have been met according to what is perceived by the community. 
They manage tourist attractions while benefiting from the tourism activities in their area. In addition, concerning the sustainability of a CBT project, Asker et al (2010) stated that to make a CBT project sustainable, the community members must participate in and benefit from tourism development.

From the aspect of ownership/management, the local community of Tamanjaya village has been involved in managing the tourism attractions. They own or run homestays. Some become tour guides, parking attendants, ticketing staff, and so on. Meanwhile from the aspect of community benefits, as they work in tourism industry, they can earn additional income. Not only from the economic perspective, the benefits are also manifested in the forms of environmental benefits, i.e. the village environment becomes cleaner and tidier. Socially, the locals also feel proud of their village as it is now becoming more popular.

From the results of interviews with the stakeholders and direct observation in the field, there are several factors or reasons that lead to the success or sustainability of CBT in Tamanjaya Village.

1) Active local management

The local management who actively participates in tourism management in Tamanjaya Village is the Sukabumi Northern Nature Association (PAPSI). Tourism attractions are also managed independently by PAPSI such as base camps and geological museums.

PAPSI is a local organization to protect/preserve and bring up the natural potential located in the southern Sukabumi. In addition, it invites the public and government in a directed and integrated way to empower5c natural resources as potential and useful human resources to achieve organizational goals optimally and sustainably. PAPSI recognizes that no advertising activities are carried out. They only post pictures and captions in the form of descriptions of locations or atmosphere around Ciletuh Geopark area and disseminate information to educational institutions, such as schools and universities around Sukabumi as well as to the nature lover communities, the lover communities of motorcycles, cars, and other communities, also through social media such as Facebook, YouTube, and blogs. (PAPSI data, 20 April 2015).

2) Private Company's Involvement

PT Biofarma is a private company that helps promote tourism activities in Geopark Ciletuh with its CSR program. Even the one who fostered the Pakidulan Alam Sukabumi Association (PAPSI) was this company. Even Tamanjaya Village is the empowerment target by the company. According to the company, Tamanjaya village has the most rapid progress as seen from the community's activities in the management of the Ciletuh Geopark Area (Darsiharjo, Supriatna, \& Saputra, 2016).

3) Role of Academics (Universities)

A lot of universities are directly involved in helping the tourism activities. For example, the Research Center for the Development of the Ciletuh Geopark Research Unit - Muhamadiyah University of Sukabumi made a report on the "Ciletuh Geopark Preliminary Study" in 2015. Telkom University through its community service program also participated in supporting activities such as the "Utilization of Drones to Increase Tourism 
Potential in Tamanjaya Village of Ciemas Sub-District, Sukabumi". In addition, the Geopark \& Geological Disaster Research Center - Padjadjaran University also researched Ciletuh Geopark. Gadjah Mada University sent student community service (KKN) teams for 2 years in a row in Tamanjaya Village.

4) Government Support

The role of the West Java Provincial Government through its Tourism and Culture Office has tried hard to develop Ciletuh Geopark, including preparing its instruments. In addition to the West Java Provincial Government, there is also the Regional Government of Sukabumi Regency who also plays a role in the development of Ciletuh Geopark. They prepared the Ciletuh National Geopark Development Acceleration document. The government agencies, concerning CBT, also help resolve land issues with residents, provide development assistance to farmers, and facilitate CSR programs of private companies. Even they grant permission to the public to manage existing tourist attractions.

\section{Constraints on Community Participation}

Tosun (2000) distinguishes three general categories of limitations on community participation. First, operational limitations. These include the centralization of tourism administration which makes it very difficult for residents to get involved, as well as lack of coordination due to fragmentation in the tourism industry. The second is structural limitations. One structural limitation is the attitude of professionals who often do not want to negotiate with the locals, or the locals are not in a favorable position to negotiate with them properly. Other structural limitations are that there is often no legal system in developing countries to protect the rights of local communities, the lack of human and financial resources, as well as the dominance of elites in tourism development. In addition, community participation is relatively time-consuming and expensive. The third is the cultural limitations. This constraint relates to the low level of awareness of the local community related to the socio-cultural, economic and political consequences of tourism development.

In the case of Tamanjaya residents, the constraints related to the management and community participation in tourism activities include:

1) Operational constraints

The majority of the residents do not participate in tourism activities due to a lack of interest in managing tourism attractions in Tamanjaya. In addition, busyness in household affairs is also a cause of low community participation. Most of them also do not know enough about the formation of Ciletuh Geopark and the essence of establishing the Geopark area. Some residents who do not engage in tourism development also claim that they are not interested in participating in activities held in the Geopark area.

2) Structural constraints

Some residents get a direct influence in the form of increased income. Nevertheless, only residents who open businesses such as food vendors receive such an increase in income. In addition, the government and local tourism management have never conducted socialization on the 
formation of Geopark. Some residents get a direct influence in the form of increased income. However, this increase was only experienced by residents who traded or were involved in tourism. Some residents even feel that they do not get any benefit from the development of tourism in their area.

Only a handful of people are active in tourism activities due to being members of local tourism management. One of them is Kang Elan who becomes PAPSI's treasurer. Therefore, the presence of Geopark tourism has not been much perceived by the community, especially in the Jayabaru hamlet. Only a few people perceive a change in economic benefits, especially from homestay rental homes. The participation of the Jayabaru community is low due to the less role of the government in inviting locals to get involved in tourism activities. This is in line with the opinions of most people who want a lot of activities and empowerment programs useful for their daily lives such as helping to improve family welfare.

3) Cultural constraints

People still have minimal knowledge about the Ciletuh Geopark. This is indicated by the majority of informants merely knowing that the Panenjoan and its surroundings are crowded by visitors. Their participation is still minimum. This is indicated by the fact that up to now there is only one resident involved in tourism activities namely Kang Ridwan who works as a guide and a parking attendant at Adelia Homestay, Panenjoan. Meanwhile, there are still many young people who do not have permanent jobs. There are still a few jobs in the field of tourism.

\section{CONCLUSION}

The factors supporting the success of the CBT project in Tamanjaya Village cannot be separated from several stakeholders who actively engage in tourism development, ranging from the private sector, academia, and government. The constrains of Tamanjaya Village's residents to participate in tourism activities include the lack of interest in being involved, the rush on household affairs, and the lack of knowledge of the Ciletuh Geopark. Several potentials can be used as attractions or supporting factors for tourism activities, including the production of chips and brown sugar.

Accordingly, this study proposes the following suggestions to address the above findings. It is necessary to have more intensive socialization to the local community, especially related to Ciletuh Geopark itself. It is important to grow the community's pride and knowledge to encourage them to participate. Moreover, the management needs to develop the existing potential such as chips and brown sugar products as souvenirs, even exploring more potential that has not been exposed.

This study implies the practical contribution for being an alternative reference to the policy on tourism activities in Ciletuh geopark, especially in Tamanjaya village. The tourism policy planning should address the community participation constraints. This is important as to sustain the tourism development in that area. From the theoretical implication, this study corroborates previous body of knowledge concerning community-based tourism especially in the context of geopark. The participation constraints found in this study also support those 
previously discovered and discussed by scholars.

\section{ACKNOWLEDGMENT}

The authors would like to express their sincere gratitude to DPPM Telkom University for the PDT Research Scheme Grant.

\section{REFERENCES}

Asker, S., Boronyak, L., Carrard, N. \& Paddon M. (2010). Effective communitybased tourism: A best practice manual. Asia pacific economic cooperation (APEC) tourism working group. Australia: Sustainable tourism cooperative research center.

Blackstock, K. (2005). A critical look at community-based tourism. Community Development Journal, 40(1), 39-49.

Darsiharjo, Supriatna, U., \& Saputra, I.M. (2016). Pengembangan Geopark Ciletuh Berbasis Partisipasi Masyarakat Sebagai Kawasan Geowisata Di Kabupaten Sukabumi. Jurnal Manajemen Resort dan Leisure, Vol.13, No.1, 55-60.

Dangi, T.B. \& Jamal, T. (2016). An Integrated Approach to "Sustainable Community-Based Tourism.Sustainability, MDPI, Open Access Journal, $8(5), 1-32$.

Dodds, R., Ali, A., Galaski, K. (2016). Mobilizing knowledge: Determining key elements for success and pitfalls in developing community-based tourism. Current Issues in Tourism, 1-22.

Ellis, S. \& Sheridan, L. (2015). The role of resident perceptions in achieving effective community-based tourism for least developed countries. Anatolia: an international journal of tourism and hospitality research, 26 (2), 244257

Giampiccoli, A., Jugmohan, S., \& Mtapuri, O. (2015). Characteristics and Policies of Community-Based Tourism in the Case of Jamaica. Caucasus Journal of Social Sciences - Business and Economics, 45-70.

Goodwin, H. \& Santilli, R. (2009). Community-based tourism: A success? ICRT Occasional Paper No. 11

Hardiyono, A., Syafri, I., Rosana, M. F., Yuningsih, E. Y., \& Andriany, S. S. (2015). Potensi Geowisata di Kawasan Teluk Ciletuh, Sukabumi, Jawa Barat. Bulletin of Scientific Contribution: GEOLOGY, 13(2).

Häusler, N. \& Strasdas, W. (2002). Training Manual for Community-based Tourism. Leipzig: InWent

Kontogeorgopoulos, N., Churyen, A., \& Duangsaeng, V. (2014). Success Factors in Community-Based Tourism in Thailand: The Role of Luck, External Support, and Local Leadership. Tourism Planning \& Development, 11(1), $106-124$.

Mann, M. (2000). The Community Tourism Guide. London: Routledge.

Miles, M.B., Huberman, A.M. and Saldana, J. (2014). Qualitative Data Analysis: A Methods Sourcebook. Sage, London.

Mitchell, J., \& Muckosy, P. (2008). A misguided quest: Community-based tourism 
in Latin America. London: Overseas Development Institute.

Scheyvens, R. (1999). Ecotourism and the empowerment of local communities. Tourism Management, 20, 245-249.

Scheyvens, R. (2002). Tourism for Development: Empowering Communities. Harlow: Pearson Education Limited

Stone, L \& Stone, T. (2011). Community-based tourism enterprises: Challenges and prospects for community participation; Khama Rhino Sanctuary Trust, Botswana. Journal of Sustainable Tourism, 19(1), 97-114.

Strydom, A.J. \& Mangope, D. (2015). Economic sustainability guidelines for a Community-Based Tourism Project: The Case of Thabo Mofutsanyane, Free State Province. African Journal of Hospitality, Tourism and Leisure, 6(3), $1-1$.

Tosun, C. (2000). Limits to community participation in the tourism development process in developing countries. Tourism Management, 21, 613-633. 